\title{
EXPLORING INTEGRATED MARKETING COMMUNICATIONS, BRAND AWARENESS, AND BRAND IMAGE IN HOSPITALITY MARKETING: A CROSS-CULTURAL APPROACH
}

\section{ISTRAŽIVANJE INTEGRIRANE MARKETINŠKE KOMUNIKACIJE, SVJESNOSTI O MARKI I IMIDŽA MARKE U MARKETINGU U UGOSTITELJSTVU: KROS-KULTURALNI PRISTUP}

Market-Tržište

Vol. 28, No. 2, 2016, pp. 159-172

UDK 640.4:658.8:658.626

Original scientific paper

\author{
Maja Šerića, Irene Gil Saurab ${ }^{b}$ Josip Mikulićc \\ a) University of Valencia, Av. de los Naranjos s/n, 46022 Valencia, SPAIN, maja.seric@uv.es \\ b) University of Valencia, Av. de los Naranjos s/n, 46022 Valencia, SPAIN, irene.gil@uv.es \\ c) University of Zagreb, J. F. Kennedy Square 6, 10000 Zagreb, CROATIA, josip.mikulic@efzg.hr
}

\section{Abstract}

Purpose - The purpose of this paper is to assess customer perceptions of integration of marketing communications, brand awareness, and brand image in hospitality. Moreover, cross-cultural differences are considered when evaluating all the concepts, since national culture can have a considerable impact on customer behavior.

Design/Methodology/Approach - After a literature review of the examined concepts, the results of an empirical study are presented and discussed. The empirical investigation was carried out by approaching 475 guests of upscale Croatian hotels. The SPSS software was employed for data analysis.

Findings and implications - The results indicate that hotel guests assessed integrated marketing communications fairly highly. Brand image also reached relatively high scores, while the level of awareness of the brand was more moderate. Significant differences in perceptions among three delimited groups according to their

\section{Sažetak}

Svrha - Osnovni cilj ovog rada jest istražiti percepcije korisnika usluga o integraciji marketinške komunikacije, svjesnosti o marki i imidža marke u području ugostiteljstva. S obzirom na to da nacionalna kultura može imati značajan utjecaj na ponašanje potrošača, u ocjeni ovih koncepata uvažavaju se kros-kulturalne razlike.

Metodološki pristup - Nakon pregleda literature koja se bavi istraživanim teorijskim konceptima, u radu se iznose i raspravljaju rezultati provedenog empirijskog istraživanja. Primarno istraživanje provedeno je u višerangiranim hotelima u Hrvatskoj na uzorku od 475 gostiju. SPSS softverski paket korišten je u obradi i analizi podataka.

Rezultati i implikacije - Prema rezultatima ovog istraživanja, hotelski gosti visoko su ocijenili stupanj integriranosti marketinške komunikacije. Oni visoko ocjenjuju i imidž marke, dok im je svjesnost o marki na srednjim razinama. Rezultati provedenih analiza nadalje upućuju 
national culture were found. The findings suggest that hotel managers should increase brand awareness and consider cross-cultural differences when implementing their business strategies.

Limitations - A greater number of hotel guests according to their national culture should be approached to obtain more representative subsamples.

Originality - The contribution of this work lies in examining three key marketing variables from the consumer point of view and under a cross-cultural approach. In particular, there has been little empirical evidence on IMC perceptions from the consumer perspective and hardly any considering the cultural background of the respondents. The contribution is also made to the hotel environment, as the variables were examined from the cross-cultural perspective, an issue that was completely neglected in the literature on hospitality marketing to date.

Keywords - integrated marketing communications (IMC), brand awareness, brand image, cross-cultural analysis, hospitality marketing na postojanje značajnih razlika u percepcijama ovisno o nacionalnoj kulturi. Prema tome, pri implementaciji poslovnih strategija hotelski bi menadžeri trebali poraditi na povećanju svjesnosti o marki te voditi računa o kros-kulturalnim razlikama.

Ograničenja - Kako bi se postigla viša razina reprezentativnosti poduzoraka, preporučuje se da se u budućim istraživanjima pokuša obuhvatiti veći broj hotelskih gostiju ovisno o njihovoj nacionalnoj kulturi.

Doprinos - Doprinos ovog rada ogleda se $u$ analizi triju ključnih marketinških varijabli iz perspektive potrošača koristeći pritom kros-kulturalni pristup. Postoji tek relativno malen broj empirijskih analiza koje su do sada istraživale percepcije potrošača o integriranoj marketinškoj komunikaciji, a gotovo nijedna ne uvažava kulturalne aspekte. Rezultati ovog rada predstavljaju doprinos i u području hotelijerstva s obzirom na to da je kros-kulturalna perspektiva potpuno zanemarena u literaturi koja se bavi marketingom u ugostiteljstvu.

Ključne riječi - integrirana marketinška komunikacija (IMK), svjesnost o marki, imidž marke, kros-kulturalna analiza, marketing u ugostiteljstvu 


\section{INTRODUCTION}

Marketing communications are not only one of the most discussed tools of the marketing mix, due to their increasing impact on both society and business practices, but also the most fascinating (De Pelsmacker, Geuens \& Van den Bergh, 2007). The Integrated Marketing Communications (IMC) approach has emerged in the last few decades and has embraced the idea of coordination and synergies of different marketing communication tools and channels to achieve the major impact (Laurie \& Mortimer, 2011). The notion of integration of marketing communications was spurred on by a number of challenges that enterprises are facing today, such as: fragmentation of the media and audiences (De Pelsmacker et al., 2007), diminishing impact of advertising (Torp, 2009), greater competitiveness (Duncan \& Everett, 1993), a need for a greater differentiation (De Pelsmacker et al., 2007), more efficient and sophisticated communication discipline (Kim, Han \& Schultz, 2004), social expectations related to desire of integration, synergies, and greater responsibility (Torp, 2009), and so on.

In particular, customer empowerment emerged as a main driving factor of IMC (Kim et al., 2004; De Pelsmacker et al., 2007). Every consumer is exposed to several marketing communication tools daily: advertising, sales promotions, direct marketing, public relations, personal selling, sponsorship, etc. In today's marketing environment, consumer himself/herself takes control of the communication process, as he/ she decides whether and when to receive the message (Kliatchko, 2008, 2009; Keller, 2009) and goes through the integration process as he/she makes sense of the received messages (Kliatchko, 2009). Considering IMC from a customer point of view is critical as IMC advocates for an "outside-in" approach, that is, first looking at the integration from the customer or prospect point of view, rather than a traditional inside-out perspective (Anantachart, 2004). Although IMC still remains the main topic in the academic research (Kliatchko, 2009), further re- search is necessary due to the lack of consumer perceptions of IMC (Šerić \& Gil-Saura, 2012). This paper attempts at addressing this issue as it examines the perceptions of IMC among customers, i.e. guests of upscale hotels.

On the other hand, brand awareness and brand image are critical for organizations as they both represent significant dimensions of brand equity (Aaker, 1991; Keller, 1993) - a term that reflects an extra value that consumers attach to a product through its brand (Pappu, Quester \& Cooksey, 2006).

In particular, brand awareness is related to the strength of a brand's presence in the customer's mind (Aaker, 1991). In turn, brand image is defined as "consumer perceptions of and preferences for a brand, as reflected by the various types of brand associations held in consumers' memory" (Keller, 2009, p. 143). In the hotel context, both variables are often examined as components of a hotel's brand equity (Kim \& Kim, 2005). However, further research on brand awareness and brand image is necessary to understand their potential in terms of their contribution to competitive advantage (Šerić, Gil-Saura \& Ruiz-Molina, 2014). Therefore, another objective of this paper is to analyze customer perceptions of these two variables in a specific context, i.e. at upscale hotels.

Finally, all the topics addressed in the paper are studied under a cross-cultural approach since we are not aware of any study that analyzes the impact of culture on the constructs analyzed here. In particular, guests' perceptions are examined in the light of their national culture after previous studies have shown that this variable can influence customers' perceptions and intentions.

\section{LITERATURE REVIEW}

\subsection{Marketing communication - an integration approach}

Marketing communications are not limited to the field of advertising any more. Under the IMC approach, the traditional rigid division between 
the "above the line" (i.e. advertising) and "below the line" tools (i.e. public relations, sales promotions, direct marketing, personal selling, sponsorship, and so on) has given way to a "through the line" approach (Schultz, 1999), where each communication tool must be combined with others to maximize its strengths and minimize its weaknesses (Anantachart, 2004). Accordingly, Thorson and Moore (1993) defined IMC as "the strategic coordination of multiple communication voices", aiming to optimize the impact of communication "by coordinating such elements of the marketing mix as advertising, public relations, promotions, direct marketing, and package design" (p. 1).

The correct implementation of IMC depends on a number of factors, such as cultural and institutional environment (Kim et al., 2004), market dynamics, media segmentation, information and communication technology available to companies (Schultz \& Kitchen, 2000), and strategic direction of the organization (Schultz \& Schultz, 1998). Thus, although there is no single pattern of successful integration, each company will undertake the challenges and opportunities of IMC in a different way. Therefore, it is possible to observe certain stages of a successful integration.

In this sense, Schultz and Kitchen (2000) have proposed a four-stage model of IMC implementation, whereas Kliatchko (2008) has suggested four basic pillars. Interrelated, the two conceptual frameworks agree on the following four phases of IMC adoption:

a) tactical coordination of marketing communications, which requires a high degree of interpersonal and cross-functional communication within the business (the "content" pillar);

b) redefining the scope of marketing communications, which implies gathering of extensive information about customers and applying it to develop marketing communications, and evaluating feedback (the "channels" pillar); c) application of information technology in order to incorporate data in communication planning and implementation effectively, aiming to turn customer data into customer knowledge (the "stakeholders" pillar); and

d) financial and strategic integration (the "results" pillar), meaning that in this final stage companies constantly monitor marketing communications from a return-on-investment (ROI) perspective.

After reviewing more than 60 empirical studies on IMC published in the last 15 years, we found the main objective of research to be actually the implementation and perception of IMC from the manager point of view, with little empirical evidence provided on IMC perceptions from the consumer perspective. In addition, very few studies on IMC were carried out in tourism-related sectors (e.g. Skinner, 2005; Dinnie, Melewar, Seidenfuss \& Musa, 2010). In particular, prior to some contributions initiated by Šerić and Gil-Saura (2012) and Šerić et al. (2014), the research on IMC within the hospitality industry was fairly neglected, even though the need for integration has proven to be as necessary there as in other industries (Hudson, 2008).

\subsection{Brand awareness and brand image}

Brand awareness is a first step towards the creation of brand equity and is defined as the potential ability of a consumer to recognize and/or remember the name of the brand (Aaker, 1991). In particular, Aaker (1991) and Keller (1993) have pointed out that brand awareness is related to the strength of the brand in the minds of consumers, as reflected in the consumer's ability to identify the brand under different conditions.

According to Keller (2003), high-level brand awareness has three types of benefits. First, awareness provides the learning advantage: the higher the level of awareness the easier it is for consumers to learn about the brand and the better the brand is registered in their mind. Second, awareness has advantages because high- 
ly visible brands can appear more easily in the consumer's consideration set. Finally, awareness delivers the choice advantage in low-involvement purchase decisions, in case of a lack of purchase motivation and/or ability.

Aaker (1991) defines three levels of brand awareness: 1) top of mind - the highest level of awareness where the brand dominates the mind and pops up as first when consumer is asked to name a brand within a product category; 2) unaided brand recall - reflects awareness of a brand when it comes to mind as soon as its product category is mentioned; and 3) brand recognition - related to familiarity and linking acquired from past exposure, it can be considered as a manner of aided recall. Similarly, Keller (2003) has argued that brand awareness consists of brand recognition and recall. While recognition implies that consumers are able to identify the brand properly as they have seen it or heard about it before, recall is based on the correct identification of the brand in a given product category. In the hotel context, brand awareness is usually estimated through top-of-mind, unaided recall (e.g. Prasad \& Dev, 2000), and brand recognition (e.g. Kim \& Kim, 2005).

On the other hand, brand image is defined as "consumer perceptions of and preferences for a brand, as reflected by the various types of brand associations held in consumers' memory" (Keller, 2009, p. 143). According to Ogilvy, consumers buy a product because it is associated with the image of the brand, and are attracted or not by a product due to its brand image. Therefore, establishment of a positive and differentiated image is critical for the success of a brand (De Salas, 2012). In this sense, the creation of brand image is a central part of the communication strategy of a company (Alba \& Hutchinson, 1987), as it facilitates knowledge, positioning, and associations with tangible and intangible features and positioning. Moreover, it contributes to the process of obtaining information, helps in the decision-making process of the consumer through differentiation and brand extension, creating positive feelings and attitudes towards the brand, and providing a reason to buy (Aaker, 1991).

In the hospitality literature, brand image is considered as both a multidimensional and a one-dimensional concept and is frequently examined together with other variables, such as loyalty, satisfaction, commitment, perceived quality, and perceived value. Thus, for example, Kandampully and Hu (2007) explored the hotel image as the antecedent of customer loyalty in five different chain hotels of New Zealand, operationalizing the construct through a holistic hotel image and attributes dimension of the hotel. Later, Ekinci, Dawes and Massey (2008) concluded that ideal self-congruence had positive effects on consumer satisfaction, while actual self-congruence was not related to consumer satisfaction. In addition, in her study carried out in 14 Italian four-star hotels, Buonocore (2010) demonstrated that perceived external organizational image significantly moderated the relationship between work status and affective commitment of organizational members, confirming the crucial role of the organizational image created for outsiders in determining organizational identification.

\subsection{Research on national culture in marketing and hospitality}

Culture is a social phenomenon of a multidimensional nature (Donthu \& Yoo, 1998) that can be classified by different typologies, such as, national, industrial, occupational, corporate, and organizational (Pizam, 1993). In the marketing literature, there is a general tendency to consider national culture as a main criterion for cross-cultural research. This can be explained by the fact that nationality is an important subcultural reference, since it influences the perceptions and opinions of consumers (Schiffman \& Kanuk, 2005).

However, certain skepticism exists around the use of nationality as a unit of measurement of culture, owing to the fact that it might cause problems of interpretation of the results, as a nation should not necessarily coincide with the 
culture identified (Tsui, Nifadkar \& Ou, 2007). Hofstede (2001) considered this problem in the analysis of the countries that had several linguistic regions (Belgium, Switzerland, Canada, and Australia), as well as regions consisting of several countries (Arab countries, West Africa, and East Africa). The case of the former Yugoslavia, for example, embraces both of these issues, as it was composed of different countries, languages, and cultures. Similarly, Donthu and Yoo (1998) underlined the lack of social and cultural homogeneity that can be found within certain countries, but also the existence of countries whose cultures overlap. Ros and Schwartz (1995) also recognized that one notion can be composed of more cultural groups and concluded that the use of this concept as a unit of measure can be misleading. In the same vein, Tsui and others (2007) pointed out that the results of studies using the nation as the unit of measure of culture do not take into account possible variations in cultural values within the nation and do not consider other factors beyond culture.

Another problem associated with the research of national culture is that the national-level individuals are selected for examination in order to reach conclusions on the entire population. Thus, the collected data represent a mix of evaluations and perceptions of different people, and patterns of associations at national culture level are different from those observed at the individual level (De Mooij, 2013). Still, as suggested by De Mooij (2013), it is also true that individual values and values at national level overlap, that individuals' behavior is reinforced by shared values of the culture they belong to and guided by their cultural priorities (Schwartz, 1994; Hofstede, 2001). Although every single individual is unique, individuals of the same national culture do fit together and produce a meaningful national picture. Therefore, in describing the national culture, it is appropriate to refer to the characteristics of individuals that are more frequent or more likely in a specific culture (De Mooij, 2013).

Moreover, while Hofstede (2001) also recognized that the nation is not the best unit to study a culture, he stressed that it is the only type of unit available for comparison. Similarly, Nakata and Sivakumar (1996) noted that, owing to the fact that it is extremely difficult to define the concept of culture, it is necessary to consider its national subcomponent in view of no other viable alternative available. Likewise, Schwartz (1999) defended the use of the nation as the unit of measure, recognizing that national boundaries do not have to correspond to the boundaries of homogeneous societies with a shared culture. In addition, he pointed out that nations are characterized by a dominant language, a common political, educational and military system, a market, shared mass-media, and a common set of national symbols. All these arguments suggest that national culture may be considered as a valid criterion for cross-cultural research in marketing.

Surprisingly, with regard to the cross-cultural research in Europe, there is a tendency to consider Europe as a whole which is quite homogeneous in cultural terms (e.g. Welzel, Inglehart \& Klingemann, 2003). Ros and Schwartz (1995) argued the existence of a Western European culture, characterized by a set of common cultural values. However, as the authors themselves noted, this does not mean that there are no differences within Western Europe, but that they are smaller than those existing, for example, between Western Europe and the rest of the world. This is the reason a number of authors prefer to examine societies that are more different from the cultural point of view.

However, this preference is rather questionable as differences between European countries do exit, despite their cultural proximity. As suggested by De Mooij (2000), the "new Europe" is not as similar as many international marketers believe. European people have different preferences, customs, and value systems. Shared cultural values are strongly rooted in history and will not disappear within the single European market, single currency, or other unification activities. Therefore, a deeper examination and understanding of differences among European countries is necessary. 
With respect to the hospitality literature, there is a general agreement that national culture should be considered as a criterion of measurement in cross-cultural research (Chen, Cheung \& Law, 2012). Chen and others (2012) have recently reviewed the development of research on culture in the hotel management field, finding that research themes relating to national culture have received the greatest attention. However, most studies have examined differences among national cultures on a broader level, rather than the European one.

With respect to subject areas examined, the authors found very few studies addressing the marketing area (mainly from the cross-cultural perspective) that were centered on the following topics: a) client satisfaction (e.g. Manzur \& Jogaratnam, 2006); b) service quality (e.g. Davidson, 2003); c) relationship marketing (e.g. Osman, Hemmington \& Bowie, 2009); d) pricing strategies (e.g. Magnini, 2009); e) behavior (e.g. Hsieh \& Tsai, 2009); and f) international marketing (e.g. Jones \& McCleary, 2004). From these findings we can conclude that cross-cultural research in the hospitality marketing literature is rather limited. In addition, there is no any empirical evidence on the constructs studied in this work within the scope of research on culture in the hotel context.

\section{RESEARCH OBJECTIVES AND METHOD}

To accomplish the main purpose of this research, we developed different specific objectives. In particular, we aimed at: a) examining the implementation of IMC from the customer perspective; b) studying the evaluation of brand awareness and brand image from the customer perspective; c) observing whether there are differences between customer perceptions according to their national cultures.

To collect data, we elaborated a structured questionnaire, consisting of closed-end questions measured on a 5-point Likert-type scale and written in English, Croatian, Spanish, and Italian. To measure IMC, we employed the adapted scale of Lee and Park (2007). These questions were adapted slightly to the hotel context. To evaluate brand awareness, we used the adapted scale of Kim, Jin-Sun and Kim (2008), which was already employed in hotels. Finally, brand image was assessed through the scale of Kim and Kim (2005), used in their study of upscale hotel companies. Before its final submission, the questionnaire was pretested on 10 individuals who have previously stayed in a hotel. Finally, it was self-administered and partially administered through personal interviews.

The empirical research was conducted in Croatia's four-star and five-star hotels located in the Dalmatia, Kvarner, and Istria regions, as well as in the capital of Zagreb. In the first place, the invitation to participate in this research was sent to 60 Croatian hotels, i.e. 27 five-star and 33 fourstar hotels. According to three experts of the Croatian hotel industry, the selected hotels were the most suitable for this research. Out of a total of 60 hotels, managers of 24 of them permitted to interview 20 guests staying in each hotel. With an extremely high response rate (98.95\%), a total of 475 guests were approached: 252 staying in 14 four-star hotels and 223 in 10 five-star hotels. The convenience sampling method was used, as hotel guests were selected on the basis of their availability and willingness to participate in the study.

\section{DATA ANALYSIS AND FINDINGS}

As presented in Table 1, out of 475 hotel guests involved, 108 (22.7\%) were from Croatia, 101 (21.3 \%) from Italy, 65 (13.7 \%) from Germany, 57 (12\%) from UK, 39 (8.2\%) from the United States, 35 (7.4\%) from Austria, and so on. As one of the objectives of our research was to test the influence of national culture on guest perceptions, we have decided to divide our sample into different subsamples. In particular, we obtained the following three subsamples

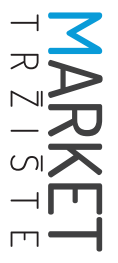


according to the guests' national culture: Croatians ( $N=108)$, Italians ( $N=101)$, and Germans and Austrians $(\mathrm{N}=101)$. According to the model of Hofstede (2001), Germans and Austrians reach similar overall country scores in some dimensions. Moreover, our study shows that these two national cultures perceive all the studied constructs similarly, which is why we believed they could be examined as a homogenous group. As this was not the case with British and American guests, we decided not to observe them as a single subsample and not to include them in the cross-cultural analysis due to the limited number of respondents.

To examine the guest perceptions of IMC, brand awareness, and brand image in upscale hotels and observe whether there are significant differences between guests coming from different cultures, descriptive statistics and nonparametric tests were carried out for data analysis, using SPSS software (version 17). The Kolmogorov-Smirnov test was first performed in order to check the normality of data distribution. The results showed that the data were not normally distributed since almost all items had critical values lower than .05. Therefore, as a non-parametric method to be performed when data do not show normal distribution, the Kruskal-Wallis test was used to determine whether the obtained differences between the three compared samples are statistically significant.

Regarding IMC, the results show that this variable received a high evaluation by all guests $(M=4.03)$. When comparing the three subsamples, we found significant differences existing between the two IMC items, i.e. consistency of marketing communication tools and channels $(p=.008)$ and brand image consistency $(p=.021)$. Croatian guests. Regarding two other subsamples, the first IMC item was assessed better by Italians, while the second one performed better among Germans and Austrians (see Table 2).
TABLE 1: Sample profile

\begin{tabular}{|l|c|c|}
\hline HOTEL GUESTS & $\mathbf{N}=\mathbf{4 7 5}$ & $\%$ \\
\hline GENDER & 246 & 51.8 \\
\hline Male & 229 & 48.2 \\
\hline Female
\end{tabular}

\section{AGE}

\begin{tabular}{|l|c|c|}
\hline $18-25$ & 34 & 7.2 \\
\hline $26-35$ & 103 & 21.7 \\
\hline $36-45$ & 142 & 29.9 \\
\hline $46-55$ & 110 & 23.2 \\
\hline $56-65$ & 64 & 13.5 \\
\hline$>65$ & 22 & 4.6 \\
\hline
\end{tabular}

\section{EDUCATION}

\begin{tabular}{|l|c|c|}
\hline Primary education & 12 & 2.5 \\
\hline Secondary education & 132 & 27.8 \\
\hline Higher education & 223 & 47.0 \\
\hline Postgraduate education & 108 & 22.7 \\
\hline
\end{tabular}

\section{OCCUPATION}

\begin{tabular}{|l|c|c|}
\hline Employee & 222 & 46.7 \\
\hline Businessman & 173 & 36.4 \\
\hline Student & 21 & 4.4 \\
\hline Housewife & 19 & 4.0 \\
\hline Retired & 34 & 7.2 \\
\hline Unemployed & 5 & 1.3 \\
\hline
\end{tabular}

\section{COUNTRY OF ORIGIN}

\begin{tabular}{|l|c|c|}
\hline Croatia & 108 & 22.7 \\
\hline Italy & 101 & 21.3 \\
\hline Germany & 65 & 13.7 \\
\hline UK & 57 & 12.0 \\
\hline USA & 39 & 8.2 \\
\hline Austria & 35 & 7.4 \\
\hline Spain & 26 & 5.5 \\
\hline Others & 44 & 9.2 \\
\hline
\end{tabular}


TABLE 2: IMC: Perceptions of hotel guests according to their national culture

\begin{tabular}{|c|c|c|c|c|c|c|c|}
\hline \multirow{2}{*}{$\begin{array}{c}\text { INTEGRATED } \\
\text { MARKETING } \\
\text { COMMUNICATIONS } \\
\text { (IMC) }\end{array}$} & \multicolumn{2}{|c|}{$\begin{array}{l}\text { TOTAL } \\
\mathrm{N}=475\end{array}$} & \multirow{2}{*}{$\begin{array}{l}\text { CRO. } \\
\mathrm{N}=108 \\
\begin{array}{c}\text { Mean } \\
\text { rank }\end{array}\end{array}$} & \multirow{2}{*}{$\begin{array}{l}\text { ITA. } \\
\mathrm{N}=101 \\
\begin{array}{l}\text { Mean } \\
\text { rank }\end{array}\end{array}$} & \multirow{2}{*}{$\begin{array}{c}\text { GER. \& AUS. } \\
\begin{array}{c}\mathrm{N}=100 \\
\text { Mean } \\
\text { rank }\end{array}\end{array}$} & \multicolumn{2}{|c|}{$\begin{array}{l}\text { Kruskal- } \\
\text { Wallis test }\end{array}$} \\
\hline & Mean & SD & & & & $x^{2}$ & $\mathbf{p}$ \\
\hline $\begin{array}{l}\text { UNIFIED } \\
\text { COMMUNICATION } \\
\text { FOR CONSISTENT } \\
\text { MESSAGE AND IMAGE }\end{array}$ & 4.03 & .879 & 176.07 & 144.14 & 143.21 & 9.694 & .008 \\
\hline $\begin{array}{l}\text { IMC1. Consistency of } \\
\text { marketing communication } \\
\text { tools \& channels }\end{array}$ & 3.99 & .980 & 174.91 & 148.26 & 140.30 & 9.657 & .008 \\
\hline $\begin{array}{l}\text { IMC2. Brand image } \\
\text { consistency }\end{array}$ & 4.08 & .923 & 173.22 & 144.07 & 146.37 & 7.766 & .021 \\
\hline
\end{tabular}

With respect to brand awareness (see Table 3), this factor received the mean value of 3.46 among all guests. The lowest evaluated items were hotel awareness $(M=3.10)$ and hotel brand awareness $(M=3.14)$, while the recall of hotel characteristics $(M=3.78)$ and the recognition of the hotel among others ( $M=3.83)$ scored the highest. The Croatian subsample assessed all these aspects with the highest scores, followed by the Italian subsample and finally by the German and Austrian subsample, which assigned the lowest of all scores. According to the Kruskal-Wallis test, these differences are statistically significant, as all the obtained $p$ values equaled .0 .
Finally, the brand image factor received a relatively high mean value $(M=3.91)$. More specifically, the following indicators were assessed highly among all guests: a) kind staff $(M=4.46) ;$ b) comfortable ( $M=4.35)$; $c$ ) cleanliness $(M=4.33)$; and $d)$ high level of service $(M=4.29)$. Once again, the items performed better among Croatian guests, except in the case of the excessive service attribute. The overall brand image was rated the lowest by Germans and Austrians, although Italian guests also assigned lower scores in a number of indicators (i.e., comfortable, high level of service, cleanliness, luxury, expensive, suitable for high-class, kind staff, excessive service, and

TABLE 3: Brand awareness: Perceptions of hotel guests according to their national culture

\begin{tabular}{|l|c|c|c|c|c|c|c|}
\hline \multirow{2}{*}{ BRAND AWARENESS } & \multicolumn{2}{|c|}{$\begin{array}{c}\text { TOTAL } \\
\text { N=475 }\end{array}$} & $\begin{array}{c}\text { CRO. } \\
\mathbf{N = 1 0 8}\end{array}$ & $\begin{array}{c}\text { ITA. } \\
\mathbf{N = 1 0 1}\end{array}$ & $\begin{array}{c}\text { GER. \& AUS. } \\
\mathbf{N = 1 0 0}\end{array}$ & \multicolumn{2}{c|}{$\begin{array}{c}\text { Kruskal- } \\
\text { Wallis test }\end{array}$} \\
\cline { 2 - 8 } & Mean & SD & $\begin{array}{c}\text { Mean } \\
\text { rank }\end{array}$ & $\begin{array}{c}\text { Mean } \\
\text { rank }\end{array}$ & $\begin{array}{c}\text { Mean } \\
\text { rank }\end{array}$ & $\mathbf{x}^{\mathbf{2}}$ & $\mathbf{p}$ \\
\hline BRAND AWARENESS & $\mathbf{3 . 4 6}$ & $\mathbf{1 . 0 5 3}$ & $\mathbf{1 9 2 . 3 3}$ & $\mathbf{1 3 9 . 3 4}$ & $\mathbf{1 3 0 . 5 1}$ & $\mathbf{2 9 . 7 4 1}$ & $\mathbf{. 0 0 0}$ \\
\hline AWE1. Hotel awarenesS & 3.10 & 1.410 & 190.74 & 144.00 & 127.52 & 29.923 & .000 \\
\hline $\begin{array}{l}\text { AWE2. Hotel brand } \\
\text { awareness }\end{array}$ & 3.14 & 1.402 & 181.29 & 142.12 & 139.61 & 15.249 & .000 \\
\hline $\begin{array}{l}\text { AWE3. Recall of hotel } \\
\text { characteristics }\end{array}$ & 3.78 & 1.142 & 184.31 & 146.01 & 132.43 & 20.884 & .000 \\
\hline $\begin{array}{l}\text { AWE4. Recognition of the } \\
\text { hotel among others }\end{array}$ & 3.83 & 1.087 & 182.83 & 141.47 & 138.62 & 17.872 & .000 \\
\hline
\end{tabular}


brand familiarity). The Kruskal-Wallis test suggested that the differences between the three defined groups are statistically significant in the case of most indicators, except the following ones: a) feeling special ( $p=0.72)$; b) excessive service ( $p=.370)$; and $c)$ different image ( $p=.290)$. All these data are presented in Table 4. and more moderate levels of brand awareness among hotel guests. In general, we also found statistically significant differences in guest evaluations among the three established groups, i.e. Croatians, Italians, and Germans and Austrians, where the group composed of Croatians evaluated all the constructs with higher scores.

TABLE 4: Brand image: Perceptions of hotel guests according to their national culture

\begin{tabular}{|l|c|c|c|c|c|c|c|}
\hline \multirow{2}{*}{ BRAND IMAGE } & \multicolumn{2}{|c|}{$\begin{array}{c}\text { TOTAL } \\
\text { N=475 }\end{array}$} & $\begin{array}{c}\text { CRO. } \\
\text { N=108 }\end{array}$ & $\begin{array}{c}\text { ITA. } \\
\mathbf{N = 1 0 1}\end{array}$ & $\begin{array}{c}\text { GER. \& AUS. } \\
\mathbf{N = 1 0 0}\end{array}$ & \multicolumn{2}{c|}{$\begin{array}{c}\text { Kruskal- } \\
\text { Wallis test }\end{array}$} \\
\cline { 2 - 8 } & Mean & SD & $\begin{array}{c}\text { Mean } \\
\text { rank }\end{array}$ & $\begin{array}{c}\text { Mean } \\
\text { rank }\end{array}$ & $\begin{array}{c}\text { Mean } \\
\text { rank }\end{array}$ & $\mathbf{x}^{\mathbf{2}}$ & $\mathbf{p}$ \\
\hline BRAND IMAGE & $\mathbf{3 . 9 1}$ & $\mathbf{. 5 8 8}$ & $\mathbf{1 8 1 . 3 3}$ & $\mathbf{1 4 4 . 2 2}$ & $\mathbf{1 3 7 . 4 5}$ & $\mathbf{1 4 . 7 3 5}$ & $\mathbf{. 0 0 1}$ \\
\hline IMG1. Comfortable & 4.35 & .752 & 175.65 & 143.36 & 144.45 & 10.582 & .005 \\
\hline IMG2. High level of service & 4.29 & .791 & 171.19 & 140.91 & 151.75 & 7.277 & .026 \\
\hline IMG3. Cleanliness & 4.33 & .843 & 170.29 & 144.25 & 149.35 & 5.973 & .050 \\
\hline IMG4. Luxury & 3.96 & .902 & 185.62 & 136.84 & 140.28 & 21.651 & .000 \\
\hline IMG5. Expensive & 3.82 & .965 & 179.66 & 132.34 & 151.26 & 16.264 & .000 \\
\hline IMG6. Suitable for high-class & 3.94 & .927 & 177.95 & 139.09 & 146.29 & 12.444 & .002 \\
\hline IMG7. Feeling special & 3.72 & 1.076 & 169.12 & 152.60 & 142.17 & 5.264 & .072 \\
\hline IMG8. Kind staff & 4.46 & .771 & 166.47 & 144.16 & 153.56 & 4.381 & .112 \\
\hline IMG9. Big and spacious & 4.17 & .940 & 170.76 & 156.19 & 136.77 & 8.901 & .012 \\
\hline IMG10. Calm and relaxing & 4.10 & .964 & 172.13 & 166.13 & 125.25 & 18.622 & .000 \\
\hline IMG11. Excessive service & 2.91 & 1.159 & 145.57 & 159.69 & 160.45 & 1.988 & .370 \\
\hline IMG12. Long history & 3.53 & 1.228 & 169.36 & 157.84 & 138.63 & 7.639 & .002 \\
\hline IMG13. Differentiated image & 3.75 & 1.091 & 163.41 & 156.10 & 144.80 & 2.479 & .290 \\
\hline IMG14. Brand familiarity & 3.39 & 1.351 & 183.57 & 139.54 & 139.76 & 18.294 & .000 \\
\hline
\end{tabular}

\section{CONCLUSION, IMPLICATIONS, AND FUTURE RESEARCH}

The aim of this study was to address three key constructs in the marketing literature from the consumer perspective, i.e. Integrated Marketing Communications, brand awareness, and brand image. The contribution is also made to the hotel environment, as the variables were examined from a cross-cultural perspective - an issue that was completely neglected in the hospitality literature to date. Our results revealed relatively high perceptions of IMC and brand image,
The results of this study have important implications for hotel marketing managers. First, as consumer opinion is crucial for the success of the IMC campaign, hotel marketers should regularly analyze consumer opinion in order to understand if their campaign works. This should help improve their efficiency through the implementation of IMC programs in general, and the transmission of unified and consistent messages in particular. More specifically, hotel managers should ensure a basic one-voice principle of IMC, meaning that a clear, consistent message should be maintained across all marketing communications tools and channels. Otherwise, 
consumers will acquire fragmented media images in a confusing marketing environment and will retain only a limited amount of information. As suggested by McGrath (2005), a brand with a consistent set of stimuli has more possibilities to deliver a single, unified message to the consumer than brands attempting to deliver different message stimuli. Therefore, marketing managers need to embrace the communication consistency in order to make their IMC campaign work.

Moreover, the results reveal a moderate perception of brand awareness among all hotel guests examined in this study. This is another important implication for hotel managers, who need to consistently assure brand awareness through the integration of their marketing communications. In particular, Croatian hotel marketers should do their best to increase both hotel awareness and hotel brand awareness since these two items scored rather low mean vales. When access to the memory of the consumer is easy and immediate, a brand will reach high levels of recognition and have a high level of awareness. This helps consumers in their purchase decision-making process, as they will consider those brands that come to mind with a small or even no effort. Marketers should be aware of the fact that brand awareness affects consumer decisions in terms of both behavior and emotional components. In this sense, with increasing brand recognition in the minds of consumers, the probability of choosing a brand will increase accordingly. In addition, a wellknown brand will create a feeling of pleasure and familiarity, which makes customers choose that specific brand instead of another. This is the major issue that Croatian hotel marketers need to address in order to increase awareness of their hotels and brands.

Another implication is that managers need to do their best to create a favorable brand image, ensure comfort, cleanliness, and a high-level of service. Specifically, hotels managers should be able to create a differentiated image, making sure that their guests feel special during their stay at the hotel. By doing so, hotels will obtain satisfied customers, who will be willing to return and give positive recommendations about the hotel.

Furthermore, marketers must take into account cultural differences that occur when evaluating hotel service, as different cultures assigned statistically different scores to the examined dimensions and their indicators. In particular, marketing activities should seek to improve the perception of all the constructs among guests from Italy, Germany, and Austria, as respondents from these countries gave lower evaluations compared to domestic guests.

More specifically, the results of our study reveal that Croatian hotel guests assessed all the examined constructs and their items fairly highly. Such a result might be culturally based and biased: it is not surprising that Croatian individuals evaluate the analyzed variables with the highest scores when assessing hotels in Croatia. However, one item of brand image was assessed rather poorly by Croatian guests when compared to the guests of other nationalities, i.e. excessive service. This finding suggests that hotel managers should try to provide superior service to Croatian guests. When addressing this aspect, they should not only meet, but rather exceed guests' expectations.

In addition, our findings show that Italian guests assigned the lowest scores to a number of items, such as: brand image consistency, suitable for high-class, and luxury hotel. Hotel marketers should therefore insure a consistent brand image within their marketing communications programs directed to the Italian market; meanwhile, they should avoid the delivery of conflicting messages from different marketing communication sources, which might have created confused brand positions and company images in the minds of Italian customers. Moreover, they should ensure superior quality to meet the luxury hotel standards, such as attractive design, high-quality furnishings, outstanding dining, and enriched service.

Regarding the evaluations of German and Austrian hotel guests, consistency of marketing 
communication tools and channels, and all brand awareness items have scored the lowest mean values, compared to those obtained from Croatian and Italian customers. On the one hand, these findings suggest that marketers of upscale Croatian hotels need to deliver a consistent message to German and Austrian customers when using various communications tools, such as advertising, PR, direct marketing, etc. and channels, like the Internet, TV, radio, brochures and catalogues, etc. This will also help project a consistent image in this specific target market. On the other hand, marketers need to enhance their communication strategies in order to increase brand awareness and familiarity among German and Austrian clients and prospects. This should be accomplished by a more intensive communication campaign, based on a close scrutiny of the stages of the customers' buying process, which should not be limited to brand awareness only, but should also embrace information search and the purchase itself. Furthermore, the results show some items being rated poorly by the guests from Germany and Austria, such as: feeling special, big and spacious, calm and relaxing. The cul- tural background of these respondents might explain some of these findings, as the notion of space and calm are understood rather differently in Northern European countries, including Germany and Austria, and Southern European countries like Italy and Croatia. However, Croatian managers should pay more attention when interacting with German and Austrian customers, making sure that they get the impression of being known and valued, as this item reached a low score.

Finally, this study has a series of limitations which should be considered in future research. A greater number of hotel guests, according to their national culture, should be reached in order to obtain a more representative sample. Hotel guests from other geographical settings should also be included. In addition, causal relationships between the examined constructs should not be overlooked.

\section{Acknowledgments}

The authors are thankful for the support of the ECO2013-43353-R project of the Spanish Ministry of the Economy and Competitiveness.

\section{References}

1. Aaker, D. A. (1991). Managing brand equity. New York, NY: Free Press.

2. Alba, J. W., \& Hutchinson, J. W. (1987). Dimension of consumer expertise. Journal of Consumer Research, 13(4), 411-453.

3. Anantachart, S. (2004). Integrated marketing communications and market planning: Their implications to brand equity building. Journal of Promotion Management, 11(1), 101-125.

4. Buonocore, F. (2010). Contingent work in the hospitality industry: A mediating model of organizational attitudes. Tourism Management, 31(3), 378-385.

5. Chen, R. X. Y., Cheung, C., \& Law, R. (2012). A review of the literature on culture in hotel management research: What is the future?. International Journal of Hospitality Management, 31(1), 52-65.

6. Davidson, M. C. (2003). Does organizational climate add to service quality in hotels?. International Journal of Contemporary Hospitality Management, 15(4), 206-213.

7. De Mooij, M. (2000). The future is predictable for international marketers. Converging incomes lead to diverging consumer behavior. International Marketing Review, 17(2), 103-113.

8. De Mooij, M. (2013). On the misuse and misinterpretation of dimensions of national culture. International Marketing Review, 30(3), 253-261.

9. De Pelsmacker, P., Geuens, M., \& Van den Bergh, J. (2007). Marketing communications. A European perspective. Harlow: Pearson Education Itd. 
10. De Salas, N. (2012). David Ogilvy: La imagen de marca como atracción de compra. Available at: http:// nicolasdesalas.com/2012/04/10/david-ogilvy-la-imagen-de-marca-como-atraccion-de-compra/ (Accessed May 2, 2012)

11. Dinnie, K., Melewar, T. C., Seidenfuss, K. U., \& Musa, G. (2010). Nation branding and integrated marketing communications: An ASEAN perspective. International Marketing Review, 27(4), 388-403.

12. Donthu, N., \& Yoo, B. (1998). Cultural influences on service quality expectations. Journal of Service Research, 1(2), 178-186.

13. Duncan, T. R., \& Everett, S. E. (1993). Client perceptions of integrated marketing communications. Journal of Advertising Research, 33(3), 30-39.

14. Ekinci, Y., Dawes, P. L., \& Massey, G. R. (2008). An extended model of the antecedents and consequences of consumer satisfaction for hospitality services. European Journal of Marketing, 42(1/2), 35-68.

15. Hofstede, G. (2001). Culture's consequences: Comparing values, behaviors, institutions and organizations across nations ( $2^{\text {nd }}$ ed.). Thousand Oaks, CA: SAGE Publications, Inc.

16. Hsieh, A. T., \& Tsai, C. W. (2009). Does national culture really matter? Hotel service perceptions by Taiwan and American tourists. International Journal of Culture, Tourism and Hospitality Research, 3(1), 54-69.

17. Hudson, S. (2008). Marketing for tourism and hospitality. A global perspective ( $2^{\text {nd }}$ ed.). London: Sage.

18. Jones, D. L., \& McCleary, K. W. (2004). A model for assessing cultural impacts on inter-national buyer-seller relationships for key accounts of hotel companies. Journal of Hospitality \& Tourism Research, 28(4), 425-443.

19. Kandampully, J., \& Hu, H. H. (2007). Do hoteliers need to manage image to retain loyal customers?. International Journal of Contemporary Hospitality Management, 19(6), 435-443.

20. Keller, K. L. (1993). Conceptualizing, measuring, and managing customer-based brand equity. Journal of Marketing, 57(1), 1-22.

21. Keller, K. L. (2003). Strategic brand management: Building, measuring, and managing brand equity ( $2^{\text {nd }}$ ed.). Upper Saddle River, NJ: Prentice Hall.

22. Keller, K. L. (2009). Building strong brands in a modern marketing communications environment. Journal of Marketing Communications, 15(2/3), 139-155.

23. Kim, H. B., \& Kim, W. G. (2005). The relationship between brand equity and firms' performance in luxury hotels and restaurants. Tourism Management, 26(4), 549-560.

24. Kim, I., Han, D., \& Schultz, D. E. (2004). Understanding the diffusion of integrated marketing communication. Journal of Advertising Research, 44(1), 31-45.

25. Kim, W. G., Jin-Sun, B., \& Kim, H. J. (2008). Multidimensional customer-based brand equity and its consequences in midpriced hotels. Journal of Hospitality \& Tourism Research, 32(2), 235-254.

26. Kliatchko, J. (2008). Revisiting the IMC construct: A revised definition and four pillars. International Journal of Advertising, 27(1), 133-160.

27. Kliatchko, J. (2009). IMC 20 years after: A second look at IMC definitions. International Journal of Integrated Marketing Communications, 1(2), 7-12.

28. Laurie, S., \& Mortimer, K. (2011). IMC is dead. Long live IMC: Academics' versus practitioners' views. Journal of Marketing Management, 27(13/14), 1464-1478.

29. Lee, D. H., \& Park, C. W. (2007). Conceptualization and measurement of multidimensionality of integrated marketing communications. Journal of Advertising Research, 47(3), 222-236.

30. Magnini, V. P. (2009). The influence of national culture on the strategic use of salesperson pricing authority: A cross-country study within the hotel industry. International Journal of Hospitality Management, 28(1), 173-176. 
31. Manzur, L., \& Jogaratnam, G. (2006). Impression management and the hospitality service encounter: cross-cultural differences. Journal of Travel \& Tourism Marketing, 20(3/4), 21-32.

32. McGrath, J. M. (2005). A pilot study testing aspects of the integrated marketing communications concept. Journal of Marketing Communications, 11(3), 191-214.

33. Nakata, C., \& Sivakumar, K. (1996). National culture and new product development: An integrative review. Journal of Marketing, 60(1), 61-72.

34. Osman, H., Hemmington, N., \& Bowie, D. (2009). A transactional approach to customer loyalty in the hotel industry. International Journal of Contemporary Hospitality Management, 21(3), 239-250.

35. Pappu, R., Quester, P. G., \& Cooksey, R. W. (2006). Consumer-based brand equity and country-of-origin relationships. European Journal of Marketing, 40(5/6), 696-717.

36. Pizam, A. (1993). Managing cross-cultural hospitality enterprises. The international hospitality industry: Organizational and operational issues. New York, NY: John Wiley.

37. Prasad, K., \& Dev, C. S. (2000). Managing hotel brand equity: A customer-centric framework for assessing performance. Cornell Hotel and Restaurant Administration Quarterly, 41(3), 22-31.

38. Ros, M., \& Schwartz, S. (1995). Jerarquía de valores en países de la Europa Occidental: Una comparación transcultural. Revista Española de Investigaciones Sociológicas (REIS), 69, 69-88.

39. Schiffman, L. G., \& Kanuk, L. L. (2005). Comportamiento del consumidor. (8 ${ }^{\text {th }}$ ed). Mexico: Prentice Hall.

40. Schultz, D. E. (1999). Integrated marketing communications and how it relates to traditional media advertising. In: J. P. Jones (Ed.), The advertising business: Operations, creativity, media planning, integrated communications (pp. 325-338). London: Sage.

41. Schultz, D. E., \& Kitchen, P. J. (2000). Communicating globally. An integrated marketing approach. Chicago, IL: NTC Publishing Group.

42. Schultz, D. E., \& Schultz, H. (1998). Transitioning marketing communication into the twenty-first century. Journal of Marketing Communications, 4(1), 9-26.

43. Schwartz, S. (1999). A theory of cultural values and some implications for work. Applied Psychology: An International Review, 48(1), 23-47.

44. Schwartz, S. H. (1994). Beyond individualism/collectivism: New cultural dimensions of values. In: U. Kim et al. (Eds.), Individualism and collectivism: Theory, method, and applications (pp. 85-119). London: Sage publications.

45. Skinner, H. (2005). Wish you were here? Some problems associated with integrating marketing communications when promoting place brands. Place Branding, 1(3), 299-315.

46. Šerić, M., \& Gil-Saura, I. (2012). ICT, IMC, and brand equity in high-quality hotels of Dalmatia: An analysis from guest perceptions. Journal of Hospitality Marketing \& Management, 21(8), 821-851.

47. Šerić, M., Gil-Saura, I., \& Ruiz-Molina, M. E. (2014). How can integrated marketing communications and advanced technology influence the creation of customer-based brand equity? Evidence from the hospitality industry. International Journal of Hospitality Management, 39, 144-156.

48. Thorson, E., \& Moore, J. (1993). Integrated communication: Synergy of persuasive voices. Mahwah, NJ: Lawrence Erlbaum Associates.

49. Torp, S. (2009). Integrated communications: From one look to normative consistency. Corporate Communications: An International Journal, 14(2), 190-206.

50. Tsui, A. S., Nifadkar, S. S., \& Ou, A. Y. (2007). Cross-national, cross-cultural organizational behaviour research: Advances, gaps, and recommendations. Journal of Management, 33(3), 426-478.

51. Welzel, C., Inglehart, R., \& Klingemann, H. D. (2003). The theory of human development: A cross-cultural analysis. European Journal of Political Research, 42(3), 341-379. 